\title{
COMPOSITION OF SOME BOTANICAL MIXTURES AS POTENTIAL FEED ADDITIVES FOR LAYING HENS
}

\author{
Iulia Varzaru ${ }^{1 *}$, Tatiana Dumitra Panaite ${ }^{2}$, Arabela Elena Untea ${ }^{2}$, Margareta Olteanu²,
} Natalita Bordei ${ }^{3}$, llie Van ${ }^{1}$

\author{
${ }^{1}$ University of Agronomic Science and Veterinary Medicine - 59 Marasti Blv. 011464, Bucharest, \\ Romania \\ ${ }^{2}$ National Research Development Institute for Animal Biology and Nutrition (IBNA), 1 Calea Bucuresti, \\ 077015 Balotesti, Ilfov, Romania \\ ${ }^{3}$ SC HOFIGAL EXPORT-IMPORT SA, 2 Intrarea Serelor, 042124 Bucharest, Romania
}

${ }^{*}$ Corresponding author:

E-mail address: iulia_maros@yahoo.com

\begin{abstract}
The aim of this study was to assess the nutritional quality of four botanical mixtures (AFC): AFC 1 (containing red corn, pumpkin pulp and marigold), AFC 2 (containing alfalfa meal, pumpkin pulp and marigold), AFC 3 (containing kale, alfalfa meal, marigold and spinach leaves), AFC 4 (containing buckthorn, red corn, pumpkin pulp and marigold), in terms of proximate analysis (crude protein, crude fat, crude fiber, ash), amino acid (AA) profile, vitamin E concentration and lutein and zeaxanthin content, in order to determine the potential of AFCs as feed additives in laying hens nutrition. The crude protein content for the analysed botanical mixtures ranged between $9.07-18.18 \%$ DM, and crude fiber between $10.41-30.83 \%$ DM. The amino acid profile of the mixture AFC 4 revealed a content of limiting essential amino acids required for laying hens: lysine $5.719 \% \mathrm{CP}$, methionine $1.058 \% \mathrm{CP}$ and threonine $4.415 \% \mathrm{CP}$. The highest content of lutein and zeaxanthin was found in the mixture AFC $4(66.659 \mathrm{mg} / 100 \mathrm{~g})$, which also had the highest amount of vitamin $E(640.93 \mathrm{mg} / \mathrm{kg})$. With regard to safety of the botanical mixtures, lead and cadmium concentrations were determined. Concentration of lead ranged from $0.28-0.75 \mu \mathrm{g} / \mathrm{g}$ DM and $0.06-0.09 \mu \mathrm{g} / \mathrm{g}$ DM for concentration of cadmium, which was within the legislation of maximal limits of EU regulations.

It can be concluded that the botanical mixture AFC 4 had the highest concentration of lutein, zeaxanthin and vitamin $\mathrm{E}$, with an adequate content of essential amino acids. Furthermore, all four botanical mixtures had high amounts of xantophylls and should be tested in laying hens trials in order to establish their effects on lutein and zeaxanthin concentration in egg yolk.
\end{abstract}

Keywords: botanical mixtures, lutein, zeaxanthin, amino acids, vitamin $E$

\section{INTRODUCTION}

Lutein and zeaxanthin are plant pigments, members of the xanthophylls family of carotenoids (Alves-Rodrigues and Shao, 2004). They are believed to be the only carotenoids vital to retinal function, being the only ones found in the macula of the retina where selectively accumulate. Within the eye, lutein has a protective role against age-related macular degeneration (AMD) which are the principal causes of blindness (Abdel-Aal et al., 2013). The mechanisms by which lutein and zeaxanthin are thought to provide protection to the eye are through their roles as blue light filters and as antioxidants (Snodderly, 1995). Animals cannot synthesize lutein and zeaxanthin, though they have the ability to absorb carotenoids from their diet and deposit them into tissue. Xanthophylls biosynthesis only takes place in plants, 
algae, bacteria and certain fungi (Kijlstra et al., 2012). Humans cannot synthesize both pigments but are able to deposit dietary pigments as absorbed or with slight modification of their structure (Larsen and Christensen, 2005). Therefore, their presence depends on entry into the organism through nutrition.

High concentrations of lutein and zeaxanthin occur in green leafy vegetables, such as spinach, kale, lettuce and broccoli (Perry et al., 2009). An important content of these xanthophylls was also reported in green bean, dill, parsley and endive (Maiani et al., 2009). Green leafy vegetables represent a rich source of lutein and zeaxanthin, but with a smaller availability when compared to eggs.

Eggs are a particularly useful source of xanthophylls pigments, as they naturally contain a relatively high proportion of lutein and zeaxanthin (Thurnham, 2007). A comparative study showed that serum lutein response following egg consumption was approximately two to three times higher as compared to lutein from spinach, because eggs provide a fat containing environment and relatively simple food matrix (Chung et al., 2004).

As with most fats and fat-soluble compounds, the composition of egg is responsive to manipulation of such nutrients in the layer diet (Leeson and Caston, 2004). Several authors reported that lutein supplementation in layer diet cause an increased lutein concentration in layers plasma (Wu et al., 2009) and in egg yolk (Leeson and Caston, 2004; Hammershøj et al., 2010; Kotrbáček et al., 2013; Englmaierová et al., 2013).

The botanical mixtures were proposed for the study by a producer of natural supplements designed for human consumption, for the recovery of the by-products resulted from the production processes. Because these mixtures were studied with the purpose of using them as feed additives, several determinations were performed beside lutein and zeaxanthin, in order to assess their nutritional quality and safety. Thus, proximate and amino acid analysis was performed. Taking into account the EU regulations for feed additives safety, the content of lead and cadmium was also determined. The vitamin $E$, which is an antioxidant found also in egg yolk, was determined in the botanical mixtures, as it can have the potential of adding nutritional value to the AFCs.

The overall aim of this study was to assess the nutritional quality of four botanical mixtures as potential feed additives in laying hens nutrition.

\section{MATERIAL AND METHODS}

The samples origin:

The botanical mixtures (AFC) were manufactured for this study by SC HOFIGAL Export-Import SA, Romania, and they were prepared from cultivated vegetable materials without using chemical stimulators (Table 1). It is intention that the AFCs with potential as feed aditives, as established by this study, are manufactured by the producer in the appropriate amounts required to conduct an experimental study on laying hens.

\section{Chemical analysis:}

The sample preparation and determination of crude protein (CP) concentrations of four AFCs were performed according to SR EN ISO 5983-2 (2009), which involved a semiautomatic Kjeldahl method using a Kjeltec auto 2300 - Tecator (Foss, Sweden). The crude fat was extracted using an improved version of the method by continuous extraction in solvent, followed by fat measurement with Soxhlet after solvent removal according to SR ISO 6492 (2001) method. The crude fibre was determined using a semiautomatic Fibertec-Tecator method (SR EN ISO $6865,2002)$ and the ash by incineration at $550{ }^{\circ} \mathrm{C}$ according to SR EN ISO 2171 (2010) method.

The AFC samples were prepared and analysed for lead $(\mathrm{Pb})$ and cadmium $(\mathrm{Cd})$ concentrations applying flame atomic absorption spectrometry (FAAS) as described by Untea et al. (2012), after the microwave digestion. The used equipment was an atomic absorption spectrometer Thermo Electron - SOLAAR M6 Dual Zeeman Comfort (Cambridge, UK), with deuterium lamp for background correction and air-acetylene flame. 
Table 1.

Botanical mixtures (AFC) composition*

\begin{tabular}{|c|c|c|c|}
\hline AFC 1 & AFC 2 & AFC 3 & AFC 4 \\
\hline $\begin{array}{l}50 \% \text { red corn } \\
\text { (Zea mays) }\end{array}$ & $\begin{array}{l}50 \% \text { alfalfa meal } \\
\text { (Medicago sativa) }\end{array}$ & $\begin{array}{l}50 \% \text { alfalfa meal } \\
\text { (Medicago sativa) }\end{array}$ & $\begin{array}{l}\text { 40\% buckthorn leaves } \\
\text { (Hippophae } \\
\text { rhamnoides L.) }\end{array}$ \\
\hline $\begin{array}{l}30 \% \text { pumpkin pulp } \\
\text { (Cucurbita maxima) }\end{array}$ & $\begin{array}{l}20 \% \text { pumpkin pulp } \\
\text { (Cucurbita maxima) }\end{array}$ & $\begin{array}{c}8 \% \text { kale leaves } \\
\text { (Brassica oleracea) }\end{array}$ & $\begin{array}{l}20 \% \text { pumpkin pulp } \\
\text { (Cucurbita maxima) }\end{array}$ \\
\hline \multirow[t]{2}{*}{$\begin{array}{l}20 \% \text { marigold flowers } \\
\text { (Tagetes erecta) }\end{array}$} & $\begin{array}{c}30 \% \text { marigold flowers } \\
\text { (Tagetes erecta) }\end{array}$ & $\begin{array}{l}\text { 34\% marigold flowers } \\
\text { (Tagetes erecta) }\end{array}$ & \multirow{2}{*}{$\begin{array}{l}20 \% \text { marigold flowers } \\
\text { (Tagetes erecta) } \\
20 \% \text { red corn } \\
\text { (Zea mays) }\end{array}$} \\
\hline & & $\begin{array}{l}8 \% \text { spinach leaves } \\
\text { (Spinacia oleracea) }\end{array}$ & \\
\hline
\end{tabular}

*The data regarding the amount of the botanicals in mixtures were provided with the consent of the producer

In order to determine the amino acids profile of the AFC samples, an HPLC Surveyor Plus Thermo Electron (Massachusetts, United States), and Hyper-SilBDS C18 column (Thermo Electron, Massachusetts, United States), dimensions 250 $\mathrm{mm} \times 4.6 \mathrm{~mm} \times 5 \mu \mathrm{m}$ were used. The samples were prepared as described by Varzaru et al. (2013).

Lutein and zeaxanthin were determined using an HPLC serie 200 (Perkin Elmer, USA) and a Nucleodur C18 ec column (Macherey-Nagel, Germany), dimensions $250 \mathrm{~mm} \times 4.6 \mathrm{~mm} \times 5 \mu \mathrm{m}$, the HPLC techniques being the most efficient for carotenoids analysis in complex mixtures (Khachik, 2009). The mobile phase consisted of acetone and water as used by Cernelic et al. (2013). For the vitamin E determination the same equipment as in the case of the amino acid analysis was used. Before chromatographic analysis, the samples were prepared (saponificated and extracted with an organic solvent), according to the method described in the Commission regulation (EU) No. 152/2009 (2009).

\section{Statistical analysis:}

All determinations were performed in triplicate. Analysis of variance (ANOVA) and Fisher's least square difference (LSD) tests were applied to compare means at $5 \%$ significance level using the statistical data analysis software StatView for MS Windows (Statistical Analysis System, Version 6.0). Results were expressed as the mean of replications $\pm S D$ for all mea- surements.

\section{RESULTS AND DISCUSSION}

The botanical mixtures examined in this study have not been investigated before, thus having an innovative character from the point of view of their composition. Several authors have studied different herbal formulas in order to observe their pigmentation ability on the egg yolk. Dried marigold petals and marigold concentrates were used as feed additives to improve the pigmentation of the poultry skin and the eggs of laying hens (Liu et al., 2011). Alfalfa concentrate, tomato powder and marigold extract, single or in mixtures, were investigated for their potential as feed additives in quail diet, increasing the yolk concentrations of lutein, zeaxanthin, lycopene and $\beta$-carotene in eggs produced by female quail fed diets supplemented with natural carotenoids (Karadas et al., 2006).

The crude protein content of the analysed botanical mixtures ranged between 9.70 $18.18 \% \mathrm{DM}$, and crude fiber between $10.41-30.83 \%$ DM (Table 2). The highest concentration of crude protein was recorded in the mixture AFC 3 (18.18\% DM), which also had the highest content of crude fiber (30.83\% DM) and ash $(8.29 \%$ DM), while the crude fat content for AFC 3 was the lowest one $(0.81 \%$ DM) from the analyzed botanical mixtures.

The results for the proximate composition ranged between the values obtained by other authors for the ingredients of our botanical mixtures. Studing the effects of 
diets including various proportions of marigold flower on the pigmentation of rainbow trout, Büyükçapar et al. (2007) reported that the proximate composition of the marigold flower was: $12.22 \%$ crude protein, $9.20 \%$ crude fat and $14.3 \%$ crude fiber. Depending on the plants stage of growth Tedeschi et al. (2001) recorded a crude protein content for alfalfa of $17.2-21.7 \%$, and Homolka et al. (2008) a crude fibre of
25.4-40.1\%. Spinach leaves were characterized by $19.82 \%$ crude protein, $3.32 \%$ crude fat, $4.92 \%$ crude fiber and $19.34 \%$ ash (Chaturvedi et al., 2013). The chemical composition of buckthorn leaves, determined by Kashif and Ullah (2013) revealed $11.06 \%$ crude protein, $5.81 \%$ crude fat, $17.31 \%$ crude fiber and $7.12 \%$ ash. In a study conducted by Pasha et al. (2013), the crude protein content of the

Table 2.

Proximate analysis of botanical mixtures (AFC)

\begin{tabular}{cccccc}
\hline AFC & dry matter & crude protein & crude fat & crude fiber & ash \\
\cline { 2 - 6 } & $\%$ & $\%$ DM & $\%$ DM & $\%$ DM & $\%$ DM \\
\hline AFC 1 & $94.82 \pm 2.8^{\mathrm{a}}$ & $9.70 \pm 0.3^{\mathrm{a}}$ & $3.57 \pm 0.1^{\mathrm{a}}$ & $10.41 \pm 0.3^{\mathrm{a}}$ & $3.53 \pm 0.1^{\mathrm{a}}$ \\
$\mathrm{AFC} 2$ & $96.05 \pm 3.8^{\mathrm{a}}$ & $16.11 \pm 0.6^{\mathrm{b}}$ & $1.67 \pm 0.05^{\mathrm{b}}$ & $28.82 \pm 1.2^{\mathrm{b}}$ & $6.78 \pm 0.2^{\mathrm{b}}$ \\
AFC 3 & $96.87 \pm 3.3^{\mathrm{a}}$ & $18.18 \pm 0.5^{\mathrm{c}}$ & $0.81 \pm 0.02^{\mathrm{c}}$ & $30.83 \pm 0.9^{\mathrm{b}}$ & $8.29 \pm 0.2^{\mathrm{c}}$ \\
AFC 4 & $94.76 \pm 3.6^{\mathrm{a}}$ & $14.18 \pm 0.5^{\mathrm{a}}$ & $4.01 \pm 0.1^{\mathrm{a}}$ & $15.29 \pm 0.4^{\mathrm{c}}$ & $5.40 \pm 0.2^{\mathrm{a}}$ \\
\hline
\end{tabular}

Results are expressed as a mean \pm SD

Values with the different superscript in the same column are statistically different $(P<0.05)$

Table 3.

Lead and cadmium concentration in botanical mixtures (AFC)

\begin{tabular}{ccc}
\hline AFC & Pb & Cd \\
\cline { 2 - 3 } & $\mu \mathrm{g} / \mathrm{g} \mathrm{DM}$ & $\mu \mathrm{g} / \mathrm{g} \mathrm{DM}$ \\
\hline AFC 1 & $0.28 \pm 0.01^{\mathrm{a}}$ & $0.08 \pm 0.005^{\mathrm{a}}$ \\
AFC 2 & $0.75 \pm 0.04^{\mathrm{b}}$ & $0.08 \pm 0.004^{\mathrm{a}}$ \\
AFC 3 & $0.57 \pm 0.03^{\mathrm{c}}$ & $0.09 \pm 0.005^{\mathrm{a}}$ \\
AFC 4 & $0.71 \pm 0.04^{\mathrm{b}}$ & $0.06 \pm 0.003^{\mathrm{b}}$ \\
\hline
\end{tabular}

Results are expressed as a mean \pm SD

Values with the different superscript in the same column are statistically different $(P<0.05)$

Table 4.

Amino acid profile of botanical mixtures

\begin{tabular}{lcccc}
\hline \multirow{2}{*}{ Amino acid } & AFC 1 & AFC 2 & AFC 3 & AFC 4 \\
\cline { 2 - 5 } & \multicolumn{4}{c}{$\mathbf{~ g / 1 0 0 ~ g ~ C P ~}$} \\
\hline Aspartic acid & $9.670 \pm 0.3^{\mathrm{a}}$ & $10.770 \pm 0.3^{\mathrm{b}}$ & $13.713 \pm 0.4^{\mathrm{c}}$ & $12.059 \pm 0.4^{\mathrm{d}}$ \\
Glutamic acid & $25.515 \pm 0.8^{\mathrm{a}}$ & $16.089 \pm 0.5^{\mathrm{b}}$ & $16.216 \pm 0.5^{\mathrm{b}}$ & $17.997 \pm 0.5^{\mathrm{c}}$ \\
Serine & $8.474 \pm 0.3^{\mathrm{a}}$ & $8.672 \pm 0.3^{\mathrm{a}}$ & $9.807 \pm 0.4^{\mathrm{b}}$ & $9.598 \pm 0.4^{\mathrm{b}}$ \\
Glycine & $5.206 \pm 0.2^{\mathrm{a}}$ & $6.511 \pm 0.2^{\mathrm{b}}$ & $7.321 \pm 0.3^{\mathrm{c}}$ & $6.685 \pm 0.2^{\mathrm{b}}$ \\
Threonine & $3.742 \pm 0.1^{\mathrm{a}}$ & $5.140 \pm 0.2^{\mathrm{b}}$ & $4.824 \pm 0.1^{\mathrm{c}}$ & $4.415 \pm 0.1^{\mathrm{d}}$ \\
Arginine & $6.423 \pm 0.3^{\mathrm{a}}$ & $5.307 \pm 0.2^{\mathrm{b}}$ & $6.023 \pm 0.3^{\mathrm{a}, \mathrm{d}}$ & $5.656 \pm 0.2^{\mathrm{b}, \mathrm{d}}$ \\
Alanine & $4.485 \pm 0.2^{\mathrm{a}}$ & $3.873 \pm 0.1^{\mathrm{b}}$ & $4.587 \pm 0.2^{\mathrm{a}}$ & $4.316 \pm 0.2^{\mathrm{a}}$ \\
Tyrozine & $1.670 \pm 0.08^{\mathrm{a}}$ & $1.533 \pm 0.07^{\mathrm{a}}$ & $1.738 \pm 0.08^{\mathrm{a}}$ & $2.116 \pm 0.1^{\mathrm{b}}$ \\
Valine & $6.052 \pm 0.3^{\mathrm{a}}$ & $6.406 \pm 0.3^{\mathrm{a}, \mathrm{b}}$ & $6.991 \pm 0.4^{\mathrm{b}}$ & $6.396 \pm 0.3^{\mathrm{a}, \mathrm{b}}$ \\
Phenylalanine & $4.938 \pm 0.2^{\mathrm{a}}$ & $4.761 \pm 0.2^{\mathrm{a}}$ & $5.539 \pm 0.3^{\mathrm{b}, \mathrm{c}}$ & $5.226 \pm 0.3^{\mathrm{a}, \mathrm{b}}$ \\
Isoleucine & $2.979 \pm 0.1^{\mathrm{a}}$ & $3.191 \pm 0.2^{\mathrm{a}, \mathrm{b}}$ & $3.520 \pm 0.2^{\mathrm{b}}$ & $3.293 \pm 0.2^{\mathrm{b}}$ \\
Leucine & $5.351 \pm 0.3^{\mathrm{a}}$ & $4.531 \pm 0.2^{\mathrm{b}}$ & $5.297 \pm 0.3^{\mathrm{a}}$ & $5.007 \pm 0.3^{\mathrm{a}, \mathrm{b}}$ \\
Lysine & $4.072 \pm 0.2^{\mathrm{a}}$ & $5.078 \pm 0.2^{\mathrm{b}}$ & $6.007 \pm 0.4^{\mathrm{c}}$ & $5.719 \pm 0.3^{\mathrm{c}}$ \\
Cystine & $1.402 \pm 0.09^{\mathrm{a}}$ & $1.124 \pm 0.07^{\mathrm{b}}$ & $0.946 \pm 0.05^{\mathrm{b}}$ & $1.058 \pm 0.07^{\mathrm{b}}$ \\
Methionine & $1.825 \pm 0.1^{\mathrm{a}}$ & $1.080 \pm 0.1^{\mathrm{b}}$ & $1.106 \pm 0.1^{\mathrm{b}}$ & $1.051 \pm 0.9^{\mathrm{b}}$ \\
\hline Resuls are & & &
\end{tabular}

Results are expressed as a mean \pm SD

Values with the different superscript in the same row are statistically different $(P<0.05)$ 
pumpkin pulp was $9.68 \%$, similar with the value registered for the mixture AFC 1 , but with the crude fiber $(0.84 \%)$ and crude fat $(0.83 \%)$ lower then the ones obtained for AFC 1.

The contaminants analysis of the four mixtures (Table 3) showed that the concentrations of lead and cadmium were below the maximal limits ( $5 \mathrm{ppm}$ for lead and 1 ppm for cadmium) allowed by the legislation in force (Regulation no. 358/15.04.2003, harmonized with EU regulations).

The method used for amino acid analysis involved determination of 15 amino acids. The AA profile contains data regarding the limiting amino acids in animal nutrition (Table 4). The amino acid determination from the four mixtures revealed that the mixture AFC 1 had the highest concentrations of sulphur essential amino acids important in human nutrition: methionine $(1.825 \% \mathrm{CP})$ and cystine (1.402\% CP). The highest content of lysine was found in the mixture AFC $3(6.007 \%$ CP), which also had the highest content of CP. The amino acid analysis of the alfalfa meal (Tkáčová et al., 2011) revealed a lysine content of $4.23 \% \mathrm{CP}$, which is closer to the value obtained for AFC 1, and a methionine content of $1.46 \% \mathrm{CP}$, higher than the values obtained for mixtures AFC 2, AFC 3 and AFC 4.

The buckthorn leaves, which represent $40 \%$ of the mixture AFC 4, were analyzed by Christaki (2012) who found a lysine content of $3.52 \% \mathrm{CP}$, and methionine and cystine concentration of $0.62 \% \mathrm{CP}$.

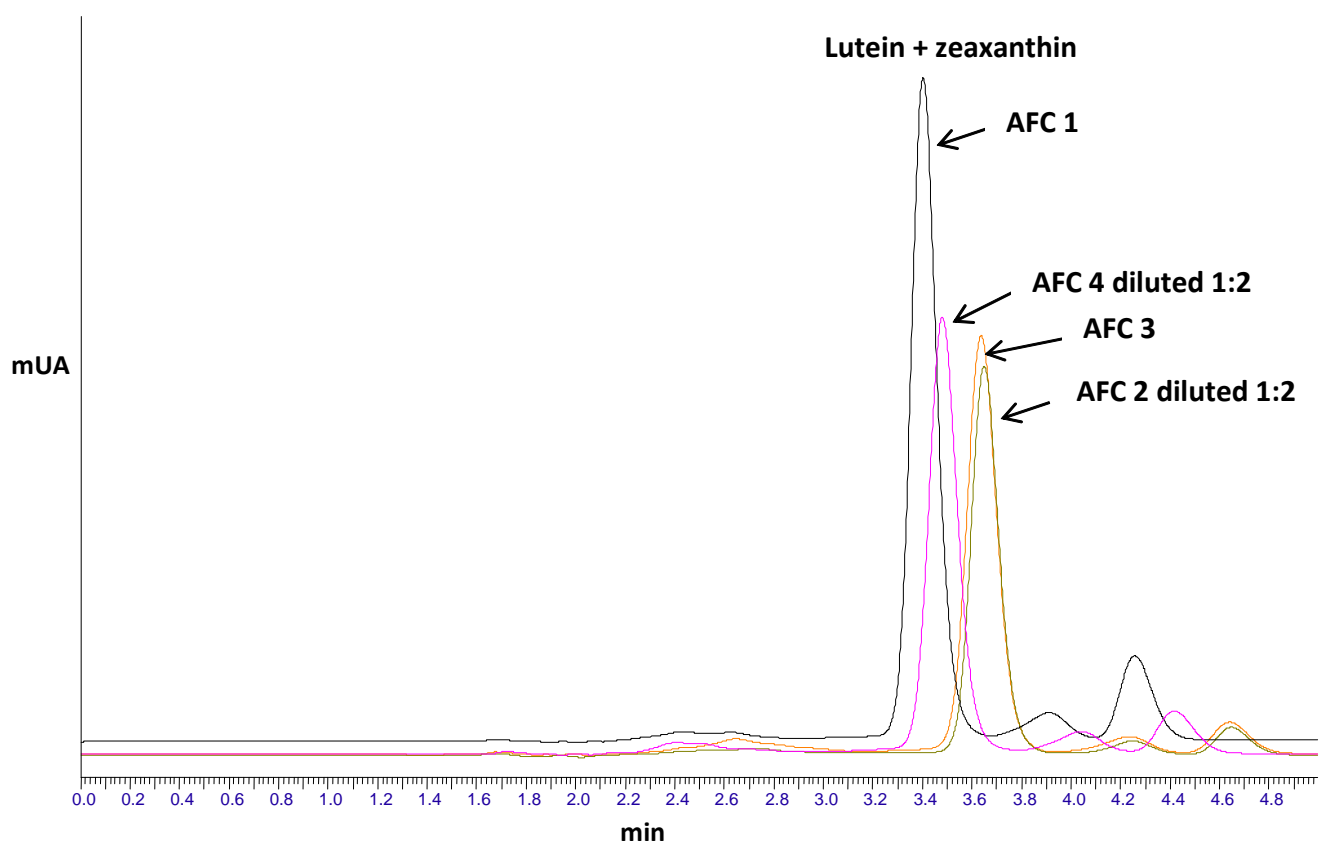

Figure 1. Overlaid chromatograms from the lutein and zeaxanthin analysis of four botanical mixtures

Table 5.

Lutein, zeaxanthin and vitamin E concentration in botanical mixtures

\begin{tabular}{ccc}
\hline Sample & $\begin{array}{c}\text { Lutein + zeaxanthin } \\
\mathbf{m g} / \mathbf{1 0 0 ~ g ~ D M}\end{array}$ & $\begin{array}{c}\text { Vitamin E } \\
\mathbf{m g} / \mathbf{1 0 0 ~ g ~ D M}\end{array}$ \\
\hline AFC 1 & $47.175 \pm 1.11^{\mathrm{a}}$ & $17.129 \pm 0.5^{\mathrm{a}}$ \\
AFC 2 & $57.503 \pm 0.67^{\mathrm{b}}$ & $13.500 \pm 0.4^{\mathrm{b}}$ \\
AFC 3 & $34.530 \pm 0.66^{\mathrm{c}}$ & $6.671 \pm 0.2^{\mathrm{c}}$ \\
AFC 4 & $66.659 \pm 1.83^{\mathrm{d}}$ & $64.093 \pm 2.2^{\mathrm{d}}$ \\
\hline
\end{tabular}

Results are expressed as a mean \pm SD

Values with the different superscript in the same column are statistically different $(P<0.05)$ 
These results are below the values determined for lysine, methione and cystine in the mixture AFC 4.

Lutein and zeaxanthin chromatographic analysis in four botanical mixtures is presented in Figure 1.

The concentrations of lutein and zeaxanthin ranged between $34.530-66.659$ $\mathrm{mg} / 100 \mathrm{~g}$ DM. (Table 5). The highest content of these xantophylls was found in AFC $4(66.659 \mathrm{mg} / 100 \mathrm{~g} \mathrm{DM}$, which also had the highest amount of vitamin $E$ (640.93 mg/kg DM) (Table 5).

Lutein is present in significant amounts in maize, alfalfa and petals of marigold, from which it is extracted for commercial use (Lavecchia and Zuorro, 2008). Analyzing different cultivars of marigold, Li et al. (2007) observed considerable variations in their lutein ester contents, ranging from 161.0 to $611.0 \mathrm{mg} / 100 \mathrm{~g}$ of flower (on DM basis). The lutein and zeaxanthin values obtained for four botanical mixtures were lower than those reported by $\mathrm{Li}$ et al. (2007) for marigold, but an increased content can be observed when comparing the data with ones recorded by Elgersma et al. (2012) when analyzing alfalfa (12.9 $\mathrm{mg} / 100 \mathrm{~g}$ ).

Guan et al. (2005) found that buckthorn fresh leaves are rich in total carotenoids $(26.3 \mathrm{mg} / 100 \mathrm{~g})$, but the registered content was lower then lutein and zeaxanthin content found in the mixture AFC 4, which had $40 \%$ of buckthorn. A study conducted by Kopsell et al. (2009) revealed that lutein content in kale can vary from 4.8$13.4 \mathrm{mg} / 100 \mathrm{~g}$, and in spinach between 6.6 - $13 \mathrm{mg} / 100 \mathrm{~g}$. Dias et al. (2009) reported a lutein concentration of $0.52-6.4$ $\mathrm{mg} / 100 \mathrm{~g}$ in kale and $3.6-5.6 \mathrm{mg} / 100 \mathrm{~g}$ in turnip leaves.

Interspecific interaction can affect leaf/stem ratio and the vitamin composition of plant organs. Leaf proportion is the largest factor affecting the a-tocopherol content in forages (Ballet et al., 2000). The buckthorn is known for the high vitamin $\mathrm{E}$ concentrations in seed oil (207 $\mathrm{mg} / 100 \mathrm{~g})$ and pulp oil (171 $\mathrm{mg} / 100 \mathrm{~g}$ ) (Zeb, 2004).

\section{CONCLUSIONS}

The nutritional quality assessment of the four proposed botanical mixtures, showed that the mixture AFC 4 (containing buckthorn, red corn, pumpkin pulp and marigold) had the highest concentration of vitamin $\mathrm{E}$, lutein and zeaxanthin, with an adequate content of essential amino acids.

All the analyzed botanical mixtures had a higher content of xantophylls compared to spinach, kale and backthron leaves, which are considered to be rich sources of lutein and zeaxanthin. The bothanical mixtures should therefore be tested in laying hens trials in order to establish the effects on lutein and zeaxanthin concentration in egg yolk.

\section{ACKNOWLEDGEMENTS}

This paper was published under the frame of European Social Found, Human Resources Development Programme 20072013, project no: POSDRU/159/1.5/S/132765

\section{REFERENCES}

1. Abdel-Aal, E. S. M., Akhtar, H., Zaheer, K., Ali, R. (2013). Dietary sources of lutein and zeaxanthin carotenoids and their role in eye health. Nutrients, 5, 1169-1185.

2. Alves-Rodrigues, A., \& Shao, A. (2004). The science behind lutein. Toxicology letters, 150, 57-83.

3. Ballet, N., Robert, J. C., Williams, P. E. V. (2000). Vitamins in Forages. In: Forage evaluation in ruminant nutrition, 399-431.

4. Büyükçapar, H. M., Yanar, M., \& Yanar, Y. (2007). Pigmentation of rainbow trout (Oncorhynchus mykiss) with carotenoids from Marigold flower (Tagetes erecta) and red pepper (Capsicum annum). Turkish Journal of Veterinary and Animal Sciences, 31 (1), 7-12.

5. Cernelic, K., Prosek, M., Golc-Wondra, A., Rodic, Z., Simonovska, B., Puklavec, M. (2013). Influence of Synthetic Antioxidants on Extraction of All-trans-Lutein from Spinach under Air and Nitrogen Atmosphere. Food and Nutrition Sciences, 4 (2), 195-200.

6. Chaturvedi, N., Sharma, P., Agarwal, H. (2013). Comparative Nutritional and Phytochemical Analysis of Spinach Cultivars: B. alba and S. oleracea. International Journal of Research in Pharmaceutical and Biomedical Sciences, 4 (2), 674-679.

7. Christaki, E. (2012). Hippophae rhamnoides L. (Sea Buckthorn): a potential source of nutraceuticals. Food and Public Health, 2 (3), 69-72. 
8. Chung, H. Y., Rasmussen, H. M., Johnson, E. J. (2004). Lutein bioavailability is higher from lutein-enriched eggs than from supplements and spinach in men. The Journal of Nutrition, 134 (8), 1887-1893.

9. Commision regulation (EC) No $152 / 2009$ (2009). Laying down the methods of sampling and analysis for the official control of feed. Official Journal of the European Union, L54/1L54/130.

10. Dias, M. G., Filomena, M., Camões, G. F. C., Oliveira, L. (2009). Carotenoids in traditional Portuguese fruits and vegetables. Food Chemistry, 113 (3), 808-815

11. Elgersma, A., Søegaard, K., Jensen, S. K. (2012). Vitamin contents in forage herbs. Aspects of Applied Biology, 115, 75-80.

12. Englmaierová, M., Skřivan, M., Bubancová, I. (2013). A comparison of lutein, spray-dried Chlorella, and synthetic carotenoids effects on yolk colour, oxidative stability, and reproductive performance of laying hens. Czech Journal of Animal Science, 58 (9), 412-419.

13. Guan T. T. Y., Cenkowski S., Hydamaka A. (2005). Effect of drying on the nutraceutical quality of sea buckthorn (Hippophae rhamnoides L. ssp. Sinensis) leaves. Journal of Food Science, 70 (9), E514-E518

14. Hammershøj, M., Kidmose, U., Steenfeldt, S. (2010). Deposition of carotenoids in egg yolk by short term supplement of coloured carrot (Daucus carota) varieties as forage material for egg laying hens. Journal of the Science of Food and Agriculture, 90 (7), 1163-1171.

15. Homolka, P., Koukolová, V., Němec, Z., Mudř́k, Z., Hučko, B., Sales, J. (2008). Amino acid contents and intestinal digestibility of lucerne in ruminants as influenced by growth stage. Czech Journal of Animal Science, 53 (12), 499-505.

16. Karadas, F., Grammenidis, E., Surai, P. F., Acamovic, T., Sparks, N. H. C. (2006). Effects of carotenoids from lucerne, marigold and tomato on egg yolk pigmentation and carotenoid composition. British Poultry Science, 47 (5), 561-566.

17. Kashif, M., Ullah, S. (2013). Chemical Composition and Minerals Analysis of Hippophae rhamnoides, Azadirachta indica, Punica granatu and Ocimum sanctum Leaves. World Journal of Dairy and Food Sciences, 8 (1), 6773.

18. Khachik, F. (2009). Analysis of carotenoids in nutritional studies. In: Carotenoids, pp. 7-44, Birkhäuser Basel.

19. Kijlstra, A., Tian, Y., Kelly, E. R., Berendschot, T. T. (2012). Lutein: more than just a filter for blue light. Progress in Retinal and Eye Research, 31 (4), 303-315.

20. Kopsell, D. A., Kopsell, D. E., Curran-Celentano, J., Wenzel, A. J. (2009). Genetic variability for lutein concentrations in leafy vegetable crops can influence serum carotenoid levels and macular pigment optical density in human subjects. Acta Horticulturae, 841, 113-117
21. Kotrbáček, V., Skřivan, M., Kopecký, J., Pěnkava, O., Hudečková, P., Uhríková, I., Doubek, J. (2013). Retention of carotenoids in egg yolks of laying hens supplemented with heterotrophic Chlorella. Czech Journal of Animal Science, 58 (5), 193-200.

22. Larsen, E., Christensen, L. P. (2005). Simple saponification method for the quantitative determination of carotenoids in green vegetables. Journal of Agricultural and Food Chemistry, 53 (17), 6598-6602

23. Lavecchia, R., Zuorro, A. (2008). Shelf stability of lutein from marigold (Tagetes erecta L.) flowers in vegetable oils. Chemical Engineering Transactions, 14, 199-204.

24. Leeson, S., Caston, L. (2004). Enrichment of eggs with lutein. Poultry Science, 83 (10), 1709-1712.

25. Li, W., Gao, Y., Zhao, J., Wang, Q. (2007). Phenolic, flavonoid, and lutein ester content and antioxidant activity of 11 cultivars of Chinese marigold. Journal of Agricultural and Food Chemistry, 55 (21), 8478-8484.

26. Liu, H., Zhang, Y., Li, Q., Zou, Y., Shao, J., Lan, S. (2011). Quantification of lutein and zeaxanthin in marigold (tagetes erecta I.) and poultry feed by ultra-performance liquid chromatography and high performance liquid chromatography. Journal of Liquid Chromatography and Related Technologies, 34 (20), 2653-2663.

27. Maiani, G., Periago Castón, M. J., Catasta, G., Toti, E., Cambrodón, I. G., Bysted, A., Granado-Lorencio, F., Olmedilla-Alonso, B., Knuthsen, P., Valoti, M., Böhm, V., Mayer-Miebach, E., Behsnilian D., Schlemmer, U. (2009). Carotenoids: actual knowledge on food sources, intakes, stability and bioavailability and their protective role in humans. Molecular Nutrition and Food Research, 53, S194-S218.

28. Pasha, I., Khan, Q. A. B., Butt, M. S., Saeed, M. (2013). Rheological and functional properties of pumpkin wheat composite flour. Pakistan Journal of Food Sciences, 23 (2), 100-104.

29. Perry, A., Rasmussen, H., Johnson, E. J. (2009). Xanthophyll (lutein, zeaxanthin) content in fruits, vegetables and corn and egg products. Journal of Food Composition and Analysis, 22 (1), 9-15

30. Snodderly, D. M. (1995). Evidence for protection against age-related macular degeneration by carotenoids and antioxidant vitamins. The American Journal of Clinical Nutrition, 62 (6), 1448S-1461S.

31. SR EN ISO 2171 (2010). Cereals, pulses and by-products - Determination of ash yield by incineration.

32. SR EN ISO 5983-2 (2009). Animal feeding stuffs - Determination of nitrogen content and calculation of crude protein content - Part 2: Block digestion and steam distillation method.

33. SR EN ISO 6865 (2002). Animal feeding stuffs - Determination of crude fibre content - Method with intermediate filtration. 
34. SR ISO 6492 (2001). Animal feeding stuffs Determination of fat content.

35. Tedeschi, L. O., Pell, A. N., Fox, D. G., Llames, C. R. (2001). The amino acid profiles of the whole plant and of four plant residues from temperate and tropical forages. Journal of Animal Science, 79 (2), 525-532.

36. Thurnham, D. I. (2007). Macular zeaxanthins and lutein-a review of dietary sources and bioavailability and some relationships with macular pigment optical density and age-related macular disease. Nutrition Research Reviews, 20 (2), 163-179.

37. Tkáčová, J., Angelovičová, M., Mrázová, L'., Kliment, M., Král, M. (2011). Effect of different proportion of lucerne meal in broiler chickens. Scientific Papers Animal Science and Biotechnologies, 44 (1), 141-144.
38. Untea, A., Criste, R. C., Vladescu, L. (2012). Development and validation of a microwave digestion-FAAS procedure for $\mathrm{Cu}, \mathrm{Mn}$ and $\mathrm{Zn}$ determination in liver. Revista de Chimie, 63 (4), 341-346.

39. Varzaru, I., Untea, A. E., Martura, T., Olteanu, M., Panaite, T. D., Schitea, M., Van, I. (2013). Development and Validation of an RP-HPLC Method for Methionine, Cystine and Lysine Separation and Determination in Corn Samples. Revista de Chimie, 64 (7), 673-679.

40. Wu, L., Huang, X., Shi, K., Tan, R. (2009). Bioavailability comparison of free and esterified lutein for layer hens. Revista Brasileira de Ciência Avícola, 11 (2), 95-98.

41. Zeb, A. (2004). Important therapeutic uses of sea buckthorn (Hippophae): a review. Journal of Biological Scien ces, 4 (5), 687-693.

\title{
САСТАВ НЕКИХ БИЉНИХ СМЕСА КАО ПОТЕНЦИЈАЛНИХ АДИТИВА У ХРАНИ ЗА КОКЕ НОСИЉЕ
}

\author{
Iulia Varzaru*, Tatiana Dumitra Panaite ${ }^{2}$, Arabela Elena Untea², Margareta Olteanu², \\ Natalita Bordei ${ }^{3}$, Ilie Van ${ }^{1}$
}

${ }^{1}$ University of Agronomic Science and Veterinary Medicine - 59 Marasti Blv. 011464, Bucharest, Romania

${ }^{2}$ National Research Development Institute for Animal Biology and Nutrition (IBNA), 1 Calea Bucuresti, 077015 Balotesti, Ilfov, Romania

${ }^{3}$ SC HOFIGAL EXPORT-IMPORT SA, 2 Intrarea Serelor, 042124 Bucharest, Romania

Сажетак: Циљ овог истраживања био је да се утврди квалитет четири биљне смесе (АФЦ): АФЦ 1 (која је садржавала црвени кукуруз, пулпу бундеве и невен), АФЦ 2 (брашно луцерке, пулпа бундеве и невен), АФЦ 3 (кељ, брашно луцерке, невен и лишће спанаћа) и АФЦ 4 (пасјаковина, црвени кукуруз, пулпа бундеве и невен), као потенцијалних адитива у исхрани кока носиља. Одређен је основни хемијски састав смеса (сирови протеини, сирова маст, сирова влакна и пепео), њихов амино-киселински састав, садржај витамина Е, као и садржај лутеина и зеаксантина. Садржај сирових протеина у биљним смесама био је у опсегу 9,07-18,18\% у сувој материји (СМ), док је садржај сирових влакна износио 10,41-30,83\% у СМ. Садржај лимитирајућих есенцијалних киселина у смеси АФЦ 4 је одговарао потребама кока носиља и садржавао је 5,719\% лизина у сировим протеинима (СП), 1,058\% метионина у СП и 4,415\% треонина у СП. Највећи садржај лутеина и зеаксантина је утврђен у смеси АФЦ 4 (66,659 $\mathrm{mg} / 100 \mathrm{~g})$, која је такође имала и највећи садржај витамина $\mathrm{E}(640,93 \mathrm{mg} / \mathrm{kg})$. У циљу утврђивања здравствене безбедности испитиваних смеса, одређене су концентрације олова и кадмијума. Концентрација олова је била у опсегу 0,28-0,75 $\mu \mathrm{g} / \mathrm{g}$ у СМ, а кадмијума 0,06-0,09 $\mu \mathrm{g} / \mathrm{g}$ у СМ, односно биле су у границама дозвољеним прописима ЕЗ.

Може се закључити да је биљна смеса АФЦ 4 имала највишу концентрацију лутеина, зеаксантина и витамина Е, са адекватним садржајем есенцијалних амино-киселина. Све четири смесе су имале висок садржај ксантофила, па би их требало испитати у огледима на кокама носиљама, како би се утврдио њихов утицај на концентрацију лутеина и зеаксантина у жуманцу јајета.

Кључне речи: биљне смесе, лутеин, зеаксантин, амино-киселине, витамин $E$ 